\title{
The Implementation of Curriculum 2013 in 1 State High School Secanggang
}

\author{
M. Irwan Syahputra \\ Teacher of 1 State High School Secanggang
}

\begin{abstract}
The implementation of the curriculum is expected to improve the quality of education. Meanwhile some difficulties could be happened in learning process. This research is conducted in order to know what are difficultier of implementation of curriculum 2013 in 1 state high school Secanggang. This research was used qualitative method research. Data was obtained through observation, interviews, and documentation of activities. The objects of this research were teachers of 1 state high school Secanggang. Based on the results of the research gained that the difficulties in the implementation of curriculum 2013 are sourced in three aspects, namely the difficulties that are sourced from the government, from the institution (school) and from the teacher itself. Governmentsourced difficulties are the lack of training and supervision of implementation of curriculum 2013. The difficulties that are sourced from institutions are the facilities of schools such as science laboratories, language laboratories, classrooms and others that are inadequate for learning practices. Other sources such as libraries are also inadequate. While the difficulties sourced from teachers are in terms of teacher readiness to study, teachers are still confused in the preparation of material that does not know the direction and difficulty of coordination between teachers in teaching materials. In addition, the assessment printing is considered too much so that the teacher should work more extra in filling the value.
\end{abstract}

\section{Keywords-Implementation, Curriculum, and difficulty}

\section{INTRODUCTION}

Curriculum is important in education. Therefore, the curriculum in the future needs to be designed and refined to improve the quality of education nationally and improve the quality of human resources of Indonesia. The curriculum is a set of plans and arrangements regarding objectives, content, and materials and the way used as a guideline for the implementation of learning activities to achieve national educational objectives [11]. In order to keep up with the times, the curriculum is constantly changing. Since Indonesia's independence period, the curriculum has undergone 11 times changes. The last curriculum changed from KTSP curriculum to curriculum of 2013. Ideally the curriculum changes are planned maturely. Things to do in curriculum changes for example: a thorough evaluation of the past curriculum, the need to analyze the challenges of the times, the preparation of curriculum devices, and the socialization optimally. The learning objectives in the curriculum of 2013 include the development of the landscape of attitudes, knowledge, and skills elaborated for each unit of education [6]. The curriculum of 2013 also stated that education assessment as the process of collecting and processing information to measure the achievement of student learning outcomes includes: authentic assessment, self-assessment, portfolio-based assessments, The daily replay, the mid-semester, final-semester exam, level of competency test, competence degree, testing, and school/madrasah exam [5].

The curriculum cannot be separated from teaching. Learning or teaching will not be effective, without the curriculum as a plan. Likewise, without learning and teaching as an implementation of a plan, the curriculum will not have any meaning. The strong curriculum and teaching relationship is also inseparable from the teacher's role. Teachers are one of the important factors in implementing the curriculum.However ideally a curriculum without being supported by the ability of the teacher to implement it, then the curriculum will not be meaningful as an educational tool and vice versa learning without a curriculum as a guideline will not be effective. Thus the role of teachers in implementing the curriculum holds key positions [7].

The importance of teacher role in curriculum implementation is basic teaching. If the teacher does not understand the curriculum, then the implementation of the curriculum will not be implemented. The curriculum of 2013 is a new curriculum. Based on this curriculum, teachers are expected to implement it so that teaching and learning is effective. However, there are still many problems in implementing this curriculum of 2013. Teachers who are not ready to face the curriculum of 2013 resulted in the teacher being confused in their implementation in the teaching and learning process. In this regard, the Government also has training for teachers to understand the curriculum of 2013. But until now there are still many teachers who have not succeeded in implementing the curriculum of 2013 in learning.

Based on the results of the assessment of the teachers who have participated in the training and successfully implemented the curriculum of 2013 in learning, the quality of learning, especially with the changing atmosphere of teaching that is more active, creative, and fun can be improved. However, there are still many teachers who have been given training yet to understand the implementation of this curriculum. This is due to some shortcomings in the training process, among others, from the time of the training that is too short, the practice method is more focused on the lecture, theory, and 
competence of the instructor itself. In fact, the process of preparing teachers through training should be emphasized on the quality improvement of the teacher, and this must be supported by quality training also. This should continue to be improved so that training is not merely a formality of activities.

The initial implementation the curriculum of 2013 has been widely received controversy. The curriculum setup for 2013 is too rushed and does not refer to the results of an already ripe study based on the results of KTSP and less attentive to the readiness of education and teacher units. In fact, this curriculum includes some important changes both from the substance side, implementation, to evaluation. Nevertheless, the curriculum of 2013 continues to be implemented gradually starting in lesson year 2013/2014. Ministry of Education and Culture (Kemendikbud) explained that in 2010-2035 is a demographic bonus for Indonesia in preparing the gold generation because the number of people with high school age. The curriculum of 2013 brings fundamental changes to teacher roles in learning. Administratively, the central government has set up a learning implementation device that no longer needs to be prepared by the teacher. However, teachers are required to play an active role as motivators and learning facilitators so that students will become learning centers. This is a separate obstacle for teachers because not all teachers have those competencies. In addition, the teacher demanded readiness to carry out the curriculum in a relatively short time while the device was not prepared in a mature way.

Based on observations at 1 State High School Secanggang, teachers were found struggling with the implementation the curriculum of 2013. The curriculum of 2013learning emphasizes text-learning and student-centered activities. Students are referred to observe, asking, reason, try and do so. While teachers are more comfortable with teacher-centered learning and in this case more actively implement the lecture methods. The teacher's handbook is still used as a material guideline to be taught, not as a guideline for implementing it in learning.

Teachers are important factors in learning. If the teacher has problems in the curriculum implementation, then the implementation in the learning also will not work well. Therefore, researchers want to investigate the teacher's constraints in implementing the curriculum of 2013 at SMA Negeri 1 Secanggang. This research is expected to be able to trace the constraints of teachers and become a literature in curriculum development that suits the needs.

\section{LITERATURE REVIEW}

\section{A. Implementation}

Implementation is a process for doing ideas, programs, or a new set of activities in the hopes that others can accept and make changes. The term implementation usually used in this field of education is detailed into three basic understandings [8].First, the implementation is related to the process. Implementation is considered as a thing to do to transfer an idea that comes up. Secondly, the implementation is related to refinements. Implementation is defined as the improvement of pre-designed programs. Third, implementation of it a curriculum program. The implementation that has been designed and refined should be implemented continuously and followed by development [7].

\section{B. Curriculum of 2013}

The curriculum of 2013 is a new curriculum that began to be applied in lesson year 2013/2014. This curriculum is the development of the curriculum that has existed before, both the competency based curriculum that has been initiated in 2004 and the Curriculum for Education unit level in 2006. The curriculum of 2013 point is the improvement and balance of soft skills and hardskills that cover the competency aspects of attitude, skills, and knowledge.

Thus, it can be understood that the curriculum of 2013 is a curriculum developed to enhance and balance the capabilities of soft skills and hard skills in the form of attitudes, skills, and knowledge [10]. In this context, the curriculum of 2013 seeks to further embed values that are reflected in attitudes that can be directly proportional to the skills obtained by students through knowledge in school bench. Soft skills and hard skills must be embedded in a balanced, adjoining, and able to be applied in everyday life. With the curriculum of 2013, students are expected to have the competencies, skills, and knowledge that increase and develop according to the education level that has been taken, so that it will influence and determine to fulfill the goal [1].

\section{RESEARCH METHODS}

The study was conducted in October until the first week of November 2017. Places or locations used by researchers are at 1 State High School Secanggang, Langkat Regency, North Sumatera. The research object in this study is the teachers of 1 State High School Secanggang who teaches in class X and XI.

Researchers use descriptive research with a qualitative approach. The methods used are observation methods, interview methods and documentation methods. The observations of researchers include what is the focus of researched studies. While through interviews, researchers prepare several questions to be used as relevant data or resources in this study [9].

\section{DISCUSSION}

Based on the results of interviews with deputy headmaster and teachers at 1 State High School Secanggangobtained the results that there are constraints in the implementation of curriculum of 2013 in 1 State High School Secanggang. These constraints include three aspects of government-sourced constraints, constraints sourced from institutions (schools) and the constraints that come from the teacher itself. The constraints in implementing the curriculum of 2013 will be described as follows.

\section{Constraints from the Government}

Based on the interview with the speaker, the first obstacle faced by the teacher is the delay of the study of textbooks to exercise. The book holds for students even to school after 
three months of activity already underway. The main type of learning resources are the designed learning resources or learning resources by design, i.e. sources that are specifically designed or developed as "instructional system components" to provide a directional and formal study facility. Teacher books and student books is an instructional source designed formally by the government in implementing the curriculum of 2013. If the books of teachers and their distribution students are problematic, learning will also be interrupted, because teacher and student books are resources specifically designed for the implementation the curriculum of 2013. Teachers are addressing these obstacles use the KTSP curriculum book and find the teaching materials yourself.

The second obstacle that comes from the government is the supply of curriculum2013 training for teachers is minimal and late. The curriculum of 2013 training is also done uneven. The interviewed teachers admitted to getting training for approximately six times. The training was held after the curriculum of 2013 was established and at the beginning of the establishment of curriculum teachers became confused how to implement it. In fact, training should be done before the curriculum is set so it does not impress trials. A speaker admitted that although it has participated in several trainings, there are still many who have not been understood especially in the artificial Lesson Plan.

\section{Constraints from Institutions}

Constraints from institutions related to the facilities and infrastructures that teachers need in the learning activities. Based on observation, 1 State High School Secanggangrequires the development of facilities and infrastructure. Learning in the curriculum of 2013 must be literacy-based. To implement this, it is necessary to support tools such as libraries and facilities to access the Internet. Based on the information from the deputy headmaster, the library cannot be enabled because the library room is used for classrooms. The books are also not much available. So if the library is used, it still doesn't meet the needs of students.

Efforts to improve student activity are done by asking students for presentations and practicing directly. Certain practicum activities are usually conducted in the laboratory. However, as with the library, the science laboratory room in the school is also used as a study room so that practicum activities can not be done. Another means of constraint is the lack of classes to learn.

Other tools that have not been fulfilled are language laboratories so that the facilities and infrastructure of education become important because the quality of education can be improved through the procurement of facilities and infrastructure.

\section{Constraints from Teachers}

Teachers are important factors in implementing the curriculum. However ideally a curriculum without the ability of teachers to implement it, then the curriculum will not be meaningful as an educational tool [8]. Thus, the role of teachers in implementing the curriculum holds key positions.
Therefore, in curriculum 2013 the teacher is a "main character" in the implementation of the curriculum must be completely prepared long before the curriculum of 2013 was decided to be implemented in the world of education in Indonesia. All teachers must be empowered and required to understand the substance of the curriculum and their implementation in the learning process.

Based on an interview on the implementation the curriculum of 2013, it was concluded that learning in class still tends to use KTSP instead tne curriculum of 2013. It was seen from the characteristics the curriculum of 2013 that has not been fulfilled in learning. The implementation of curriculum 2013 in 1 State High School Secanggangshouldbe in accordance with the characteristics of curriculum 2013 as a whole.

According to Murray Printer as quoted by Vienna Sanjaya, the role of teachers in curriculum development in the classroom setting is as the implementer of the curriculum. As implementer, the teacher plays a role in running the existing curriculum. Teachers have no space to determine the curriculum content or the target of the curriculum itself. In carrying out its role, the teacher only accepts a wide range of curriculum policies that are centrally designed by the teaching Program outlines. But if the teacher himself does not master the curriculum to be applied, then the curriculum is only as writing. Curriculum changes do raise challenges for teachers as implementer. Based on this, the constraints contained in the implementation the curriculum of 2013 can be completed immediately.

Based on the interview, the implementation constraint curriculum of 2013 also comes from the teacher. Teachers initiative to study the curriculum of 2013 is still lacking. Based on the information of deputy headmaster, teachers tend to wait for training from the government. The desire to learn the curriculum is not so great. That's why teachers struggle to make Lesson Plan.

Another obstacle is that the available teacher has not fulfilled the need. Due to lack of teachers, cross-interest applications are not met because Indonesian teachers are still lacking.

\section{CONCLUSION}

The constraints experienced by 1 State High School Secanggang North Sumatra in the implementation of curriculum 2013 include human resources and facilities. Constraints originating from the government include a slow supply of 2013 curriculum training and a lack of a K13 handbook that is distributed for teachers. Constraints in terms of human resources include a lack of educators at the school so that cross interest is not appropriate. In addition, a late supply of human resources or educators is experiencing difficulties. Constraints originating from institutions such as lack of class number, cannot be functioned by the library of school, at least collection of books, can not be functioned Science laboratories, and the absence of language laboratories.

In connection with these constraints, it is advisable to the government especially the Ministry of Education and Culture 
to provide the implementation of curriculum 2013, especially in terms of the preparation and distribution of books and technical guidelines assessment learning. To the institution it is advisable to prepare facilities to support the implementation of curriculum 2013. Advice to teachers is to utilize the interteacher meeting forum to learn about the 2013 curriculum.

\section{REFERENCES}

[1] Hamalik, Oemar. 1992. Administrasi dan Supervisi Pengembangan Kurikulum. Jakarta:Mandar.

[2] Hill, M. and Hupe P. 2009. Implementing Public Policy. California: Sage Publication.Inc.
[3] Moleong. 2006. Metodologi Penelitian Kualitatif. Bandung :PT Remaja Rosdakarya.

[4] Muhadjir. 2000. Metodologi Penelitian Kualitatif. Yogyakarta : Rake Sarasin.

[5] Permendikbud No. 66 Tahun 2013 Tentang Standar Penilaian.

[6] Permendikbud No 54 Tahun 2013 Tentang Standar Kompetensi Lulusan.

[7] Sanjaya, Wina. 2010. Kurikulum dan Pembelajaran. Jakarta: Kencana.

[8] Soetjiptodan Raflis Kosasi.2004.Profesi Keguruan.Jakarta:Rineka Cipta.

[9] Sugiyono. 2007. Metode Penelitian Pendidikan Pendekatan Kuantitatif, Kualitatif dan $R \& D$ Bandung : Alfabeta.

[10] Tilaar \& Riant Nugroho. 2008. Kebijakan Pendidikan: Pengantar untuk Memahami Kebijakan Pendidikan sebagai Kebijakan Publik. Yogyakarta: Pustaka Pelajar.

[11] UU No.20 Tahun 2003. Sistem Pendidikan Nasional. 